\title{
Baseline Antibody Titer against Salmonella enterica Subspecies enterica serovar Typhi and Paratyphi among Healthy Individuals from Meerut City: A Periodic Evaluation
}

\author{
Abhigyan Goel, Navdeep Gambhir, Arjun K. Bisht and Anita Pandey* \\ Department of Microbiology, Subharti Medical College, Meerut, Uttar Pradesh 250001, India \\ *Corresponding author
}

\section{A B S T R A C T}

\begin{tabular}{|l|}
\hline Ke y w or d s \\
Enteric fever, \\
Widal, Baseline \\
titer, Salmonella, \\
Endemic \\
\hline Article Info \\
\hline Accepted: \\
17 September 2019 \\
Available Online: \\
10 October 2019 \\
\hline
\end{tabular}

Enteric fever is an endemic disease in India and Widal test is widely used for its diagnosis and to plan treatment. Interpretation of Widal test depends upon the antibody titer present amongst the healthy, asymptomatic individuals in that geographical area. Aim: To determine the Endemic titer of Salmonella enterica subspecies enterica serovar Typhi and Paratyphi among healthy individuals in Meerut City and to find out the local recommendations for the interpretation of Widal test. Materials and methods: A total of 600 serum samples collected from healthy individuals were subjected for Widal tube agglutination test with commercially available antigens of Salmonella enterica subspecies enterica serovar Typhi $\mathrm{O}$ and $\mathrm{H}$ antigens, serovar paratyphi $\mathrm{AH}$ antigen and paratyphi $\mathrm{BH}$ antigen . Interpretation of the test was done using standard guidelines. Result: Majority of the samples tested $79.33 \%, 92 \%, 94.33 \%$ and $100 \%$ had a titer of $\leq 1: 20$ for anti-O agglutinins, anti-H agglutinins, anti - $\mathrm{AH}$ agglutinins and anti- $\mathrm{BH}$ agglutinins respectively. The baseline endemic titer was up to 1:80 for $S$. typhi $\mathrm{O}$ and $\mathrm{H}$, upto 1:40 for $S$. paratyphi $\mathrm{AH}$ is and upto 1:20 for $\mathrm{BH}$. Conclusion: Periodic evaluation of baseline antibody titer in a healthy population is important because the titer may change over the years. Knowledge of the baseline antibody titer in that geographical area will help in proper interpretation of the test result which will ultimately decide the treatment outcome of the patient and limit antimicrobial resistance

\section{Introduction}

'Enteric fever' is an endemic infection in India and includes typhoid and paratyphoid fever which is caused by $S$. typhi and S. paratyphi A and Brespectively. ${ }^{1}$ Definitive diagnosis of enteric fever depends on isolation of Salmonella species from blood, stool, urine, bone marrow, bile or other body fluids. ${ }^{2-4}$
However, the isolation rate of Salmonella is comparatively less in our setting because our center, being a tertiary care hospital patients usually come to us after having sought medical advice from local doctors and having taken multiple or incomplete course of antibiotics, which leads to low isolation rates in clinically suspected cases of Enteric fever. Widal testis the mainstay of diagnosis of 
Enteric fever in such cases. ${ }^{5}$ However, interpretation of the Widal test depends upon the baseline titer amongst the healthy individuals in that particular geographical area which may change over the years. Therefore, periodic evaluation of baseline titer is mandatory for proper interpretation of Widaltest. ${ }^{6}$ Previousstudy from Meerut was carried out 5-6 years back byGoyalet.al. ${ }^{7}$

To the best of our knowledge re-evaluation of baseline titer from this geographical area has not been attempted since then. Therefore, this study was carried out to re-evaluate the baseline antibody titer against Salmonella enteric subspecies enteric serovar Typhi and paratyphi among healthy individuals in Meerut City so that a significant cut off titer can be redefined for better clinical outcome of our patients in a single unpaired test.

\section{Materials and Methods}

A cross sectional study was carried out in Clinical Laboratory, Department of Microbiology, Subharti Medical College, and associated Chattarpati Shivaji Subharti Hospital, a Tertiary care Hospital in Meerut City, for period of 6 months from October' 18 to March'19,with the aim tore-evaluate the baseline antibody titer against Salmonella enterica serotypes Typhi and Paratyphi among healthy individuals from Meerut City.

\section{Study population}

A total of 600healthy individuals participated in this study. The participation of the subjects was voluntary. Informed Consent was taken from all participants involved in the study after explaining about the purpose of the study. The sera were screened for the antibody against the Salmonella enteric subspecies enterica serotypes, Typhi $\mathrm{O} \& \mathrm{H}$, paratyphi $\mathrm{AH}$ and paratyphi $\mathrm{BH}$ by the Widal tube agglutination test.

\section{Inclusion criteria}

All age group

Both genders

Participants belonging to Meerut region

Participants with no history of fever

Participants with no history of antibiotic intake

Participants who have not received any vaccination for enteric fever

\section{Exclusion criteria}

Participants not belonging to Meerut region

Participants with history of fever and antibiotic intake

Participants who had received vaccination for enteric fever in the past

\section{Ethical approval}

Approval from the Institutional Ethical and Research Committee was obtained before conducting the study.

\section{Sample processing}

About $5 \mathrm{ml}$ of venous blood sample (nonrepetitive) was collected from each participant. The serum was separated, properly labeled and stored at $2-8^{0} \mathrm{C}$ till the test was performed. Widal tube agglutination test was performed to detect the titer of antibody in the participant's sera. Commercially available antigens which contained the Salmonella enteric subspecies enteric serovar Typhi $\mathrm{O}$ and $\mathrm{H}$ antigens, the Salmonella enteric subspecies enterica serovar Paratyphi $\mathrm{AH}$ antigen and the 
Paratyphi BH antigen from (Span Diagnostics Ltd) was used. Briefly, the serial doubling dilution of sera in $0.9 \%$ normal saline was prepared from 1:20 to 1:320. Equal volume of antigen was added in each designated row and the tubes were then incubated overnight at $37^{\circ} \mathrm{C}$ in a water bath and each tube was checked visually for the agglutination. If antiSalmonella antibody was present in the serum it reacted with the corresponding antigens to give agglutination.

The ' $\mathrm{O}$ ' antigen being a somatic antigen, caused a granular agglutination at the bottom of the tube resembling "carpet formation", whereas ' $\mathrm{H}$ ' antigen being a flagellar antigen, caused "loose, cotton wool clump" like agglutination.

Control tubes (antigen, normal saline without sera) were included with each batch of test.The results were interpreted and analyzed as per the standard guidelines as follows: ${ }^{8}$

Control tubes represented as "button formation", a compact deposit at bottom of the tube.

Negative test was represented as "button formation", a compact deposit at bottom of the tube.

The positive antibody titers were taken as the highest dilutions of serum with a visible agglutination.

\section{Results and Discussion}

Out of the 600 samples tested, titer of $\leq 1: 20$ was observed in $79.33 \%, 92 \%, 94.33 \%$ and $100 \%$ healthy participants for anti-O agglutinins, anti-H agglutinins, anti - $\mathrm{AH}$ agglutinins and anti- $\mathrm{BH}$ agglutinins respectively. Analysis of data of the present study has shown that the baseline endemic titer for Salmonella Typhi $\mathrm{O}$ and $\mathrm{H}$ is upto
1:80, for Salmonella paratyphi $\mathrm{AH}$ isupto1:40and for $\mathrm{BH}$ is $\leq 1: 20$ from this geographical area [Table 1].

Therefore, based on the results of our study, the following observations could be made i) The cut-off titers for interpretation of Widal test should be $\geq 1$ : 160 for anti-O \& anti-H antibody, $\geq 1$ : 80 for anti-AH antibody and $\geq 1: 40$ for anti-BH antibody. ii) No significant rise in endemic titer of Salmonella species has been observed over the last so many years in Meerut city. The healthy volunteers were predominantly in the age-group of 11-21 years $(n=206)$ followed by $21-30$ years $(n=194)$ [Table 2]. On gender wise distribution it was seen that the volunteers were predominantly males $372(62 \%)$ as compared to females 228 (38\%). The female: male ratio was 1: 1.6 [Figure 1].

Enteric fever is endemic in India and it continues to be one of the major health problems. ${ }^{9}$ Blood culture for detection of Salmonella species isthe gold standard method for diagnosis of enteric fever in the first few days of infection. Unfortunately the sensitivity of the blood culture is low which one of its limitations.

Widal is a tube agglutination test and ideally paired samples are recommended to look for rise in antibody titer. However, this may not always be feasible due to cost to patients especially in a developing country like ours; hence in such a situation single antibody titer, higher than the community titer may be considered as diagnostic. 1,10

Correct interpretation of Widal test depends on the cut-off titer which is derived from the baseline antibody titer against Salmonella species present in the healthy population in that geographical area. This baseline antibody titer needs to be updated and re-evaluated periodically because the variation in titer depends on the degree of its endemicity in that 
area, which may change over time. ${ }^{11}$ The present study was carried out to re-evaluate the baseline antibody titer against Salmonella enteric subspecies enteric serovar Typhi and paratyphi among healthy individuals in Meerut City so that a significant cut off titer can be redefined for better clinical outcome of our patients in a single unpaired test. Previous study from Meerut City was carried out by
Goyal et al., in 2015 to determine the significant cut off titer for typhoid/paratyphoid infection.

Out of 600 samples tested, 79.33\%, $92 \%, 94.33 \%$ and $100 \%$ healthy participants had a titer of $\leq 1: 20$ for anti-O agglutinins, anti-H agglutinins, anti - $\mathrm{AH}$ agglutinins and anti- $\mathrm{BH}$ agglutinins respectively in our study.

Table.1 Distribution of antibody against various antigens of Salmonella

\begin{tabular}{|c|c|c|c|c|c|}
\hline \multirow[b]{2}{*}{$\begin{array}{c}\text { Salmonella } \\
\text { Antigen }\end{array}$} & \multicolumn{5}{|c|}{ Antibody Dilution } \\
\hline & $\leq 1: 20$ & $1: 40$ & $1: 80$ & $1: 160$ & $1: 320$ \\
\hline S. typhi O & $\begin{array}{c}476 \\
(79.33 \%)\end{array}$ & $\begin{array}{c}108 \\
(18 \%)\end{array}$ & $\begin{array}{c}16 \\
(2.66 \%)\end{array}$ & 0 & 0 \\
\hline S. typhi $\mathbf{H}$ & $\begin{array}{c}552 \\
(92.00 \%)\end{array}$ & $\begin{array}{c}42 \\
(7 \%)\end{array}$ & $\begin{array}{c}8 \\
(1.33 \%)\end{array}$ & 0 & 0 \\
\hline S. paratyphi AH & $\begin{array}{c}566 \\
(94.33 \%)\end{array}$ & $\begin{array}{c}34 \\
(5.66 \%)\end{array}$ & (2) & 0 & 0 \\
\hline S. paratyphi BH & $\begin{array}{c}600 \\
(100 \%)\end{array}$ & 0 & 0 & 0 & 0 \\
\hline
\end{tabular}

Table.2 Age \& gender wise distribution of participants

\begin{tabular}{|c|c|c|c|}
\hline Age & $\begin{array}{c}\text { Male } \\
(\mathbf{n = 3 7 2})\end{array}$ & $\begin{array}{c}\text { Female } \\
(\mathbf{n = 2 2 8})\end{array}$ & Total \\
\hline $\mathbf{0 - 1 0}$ & 2 & 2 & 4 \\
\hline $\mathbf{1 1 - 2 0}$ & 140 & 66 & 206 \\
\hline $\mathbf{2 1 - 3 0}$ & 114 & 80 & 194 \\
\hline $\mathbf{3 1 - 4 0}$ & 46 & 34 & 80 \\
\hline $\mathbf{4 1 - 5 0}$ & 22 & 14 & 36 \\
\hline $\mathbf{5 1 - 6 0}$ & 12 & 20 & 32 \\
\hline $\mathbf{> 6 1}$ & 36 & 12 & 48 \\
\hline
\end{tabular}


Fig.1 Gender wise distribution of participants

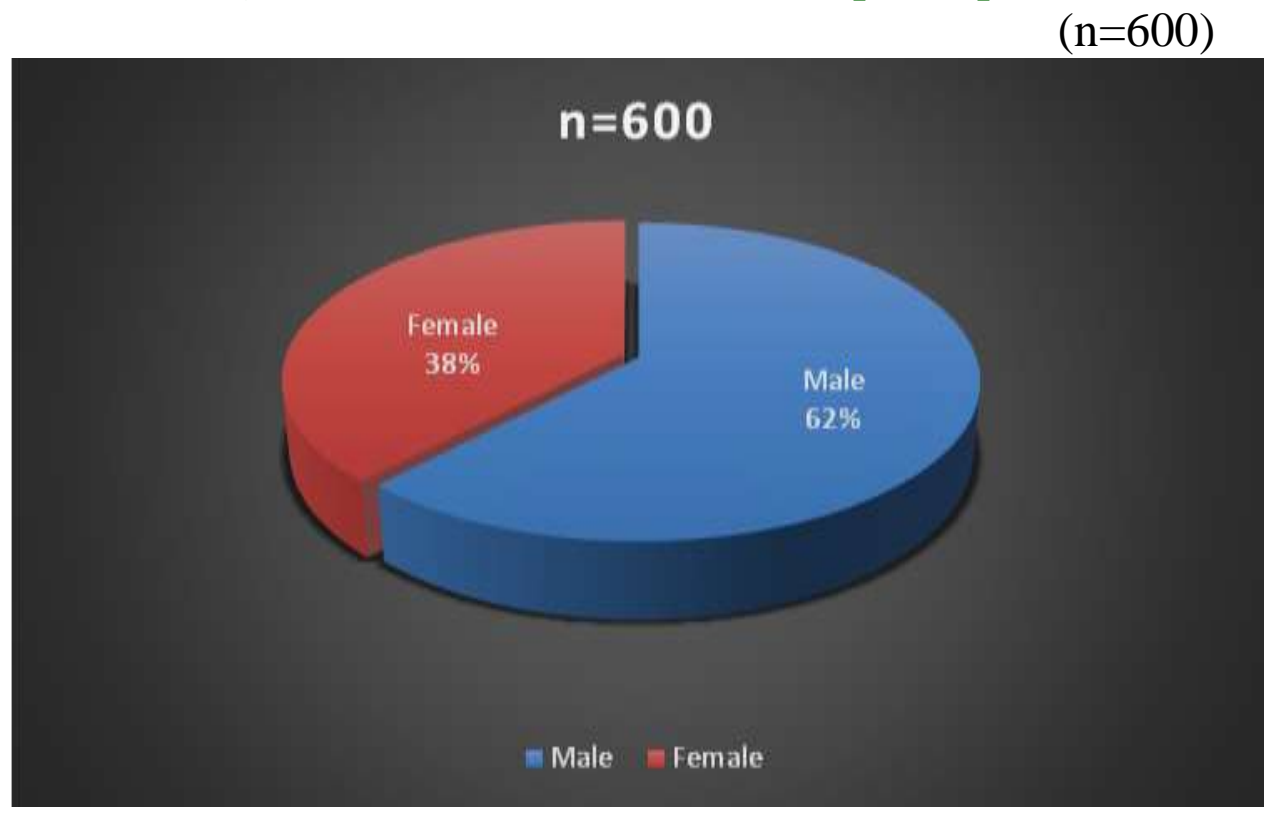

\section{References}

Ananthanarayan R, Paniker CKJ. Textbook of Microbiology. 8th ed. Hyderabad: Orient Longman Enterobacteriaceae III: Ch. 32. Salmonella; 2011. pp. 288301.

Manson-Bahr PEC, Bell DR. Manson's tropical diseases London. BailliereTindall. 1987:194-206.

Gilman RH, Terminel M, Levine MM, Hernandez-Mendoza P, Hornick R. Comparison of relative efficacy of blood, stool, urine, bone marrow and rose spot cultures for recovery of Salmonella typhi in typhoid fever. Lancet. 1975; 1: 1211-15.

Gaddes AM. Imported infections. Unexplained fever. BMJ. 1974; 4:39798.

Olopaenia LA, King AL. The Widal agglutination test- 100 years later: Still plagued by controversy. Postgrad Med. J. 2000; 76:80-4.

Gunjal SP,Gunjal PN, Patil NK, Vanaparthi N, Nalawade AV, Banerjee Set al., Determination of baseline Widal titres amongst apparently healthy blood donors in Ahmednagar, Maharashtra, India.Jou.ClinDiagn Res.2013; 7: 2709-11.

Goyal R, Rangari A.A, Kumar A. Determining significant cut off titre of single widal test for identifying presence of active typhoid/paratyphoid infection by studying baseline endemic widal titres from Meerut (UP), India \& adjoining sub-urban regions. Biomedical Review: Journal of Basic and Applied Medical Sciences.2015; 2 (3): 49-55. Available online at: www.biomedicalreview.in

Freeman R. Bacterial immunoserology. In: Kaufmann SHE and Steward MW (eds) Topley and Wilson's Microbiology and Microbial infections, 10th edn. Baltimore, MD: Edward Arnold Publishers, 2005, p.74

Punia JN, Joshi RM, Gupta V, Arora RK. Determination of the baseline Widaltitre in Chandigarh. Ind. Journal of Medical Microbiology. 2003; 21 (2): 144.

Chandrashekar, S.C. and Sudeepkumar, M. 
2018. Determination of Widal Baseline Titre among Healthy Adult Individuals in Tumkur India. Int.J.Curr.Microbiol.App.Sci. $\quad 7(02)$ : 957962.https://doi.org/10.20546/ijcma s.2018.702.119

Kataria VK, Bhai N, Mahawa lBS, Roy RC. Determination of baseline Widaltitre among apparently healthy population in Dehradun City. IOSR Journal of Pharmacy and Biological Sciences. 2013; 7(2): 53-5
Mittal G, Gupta P, AgarwalRK, Manjubala T, Negi G, Gupta S. Evaluation of the baseline Widal titres in healthy blood donors of Uttarakhand; Indian Journal of Community Health.2014; 26 (3):

Sreenath K, Sebastian S, Deepa R. Detection of baseline Widal titres among the blood donors: A population based study. International Journal of Current Microbiology and Applied Sciences. 2014; 3(1): 428-31.

\section{How to cite this article:}

Abhigyan Goel, Navdeep Gambhir, Arjun K. Bisht and Anita Pandey. 2019. Baseline Antibody Titer against Salmonella enterica Subspecies enterica serovar Typhi and Paratyphi among Healthy Individuals from Meerut City: A Periodic Evaluation. Int.J.Curr.Microbiol.App.Sci. 8(10): 2264-2269. doi: https://doi.org/10.20546/ijcmas.2019.810.262 